Article

\title{
An Influence of Group Purchasing Organizations on Financial Security of SMEs Operating in the Renewable Energy Sector-Case for Poland
}

\author{
Grzegorz Zimon ${ }^{1, *(1)}$, Marek Sobolewski ${ }^{2}$ a and Grzegorz Lew ${ }^{1}(\mathbb{D}$ \\ 1 Department of Finance, Banking and Accountancy, The Faculty of Management, Rzeszow University of \\ Technology, 35-959 Rzeszow, Poland; lewgrzes@prz.edu.pl \\ 2 Department of Quantitative Methods, The Faculty of Management, Rzeszow University of Technology, \\ 35-959 Rzeszow, Poland; msobolew@prz.edu.pl \\ * Correspondence: gzimon@prz.edu.pl; Tel.: +48-603979034
}

Received: 18 May 2020; Accepted: 5 June 2020; Published: 7 June 2020

\begin{abstract}
European countries are increasingly using renewable energy. Poland is an outsider of such solutions. The Polish energy sector is primarily based on energy produced from coal. However, environmental changes and regulations of the European Union are forcing the increased use of energy from renewable sources. Renewable energy is an industry that is still developing in Poland. At the same time, Poland is a country where the political decisions of the government over the last few years have resulted in a significant limitation of the possibilities of renewable energy development. These actions have also resulted in lowering the profitability of the currently operating renewable energy enterprises, especially those from the sector of small and medium-sized enterprises. An opportunity for SMEs operating in the renewable energy sector is to merge into industry purchasing groups. The aim of the article-and at the same time the research question-is: Is it financially safer for renewable energy companies to operate within purchasing groups compared to companies operating independently in this industry? Traditional ways of purchasing can be transferred to integrated purchasing systems, which will be created by purchasing groups associating renewable energy companies. For this purpose, the financial effects of the implementation and functioning of the purchasing groups in the renewable energy sector in relation to entities operating independently were examined. In the research of renewable energy SMEs, a comparative analysis of key indicators determining the possibility of continuing the activity of these entities was made. The following indicators were examined: current financial liquidity ratio, return on sales, operating cycle, cash conversion cycle, share of receivables in current assets, share of inventory in current assets, turnover ratios, level of receivables, liabilities and profitability. The scientific literature is dominated by studies on purchasing groups in the pharmaceutical and construction industries. Thanks to the research conducted, it has been indicated that the renewable energy industry can also improve its profitability, and thus the possibility of safe continuation of operations by extending the business model to inter-entity cooperation within purchasing groups. Increasing the efficiency of individual entities of the renewable energy industry within purchasing groups becomes particularly important during the COVID-19 pandemic. Statistical analyses and their graphic presentation present the significant impact on the safety and profitability of renewable energy entities in the form of purchasing groups.
\end{abstract}

Keywords: renewable energy; Polish energy; group purchasing organizations; financial liquidity; bankruptcy 


\section{Introduction}

Europe is trying to move away from gas and nuclear energy, but the Polish economy is still a coal-based one. Polish coal is expensive, which results from high administrative and mining costs. Coal deposits in mines are at a very deep level, which hinders mining and increases its costs compared to foreign mines. The policy of Poland should be aimed at limiting the production of energy from coal. However, once again the plans have not been implemented, which resulted in an increase in coal energy production in 2018. Today, mines face another problem: coal is expensive and does not sell well, so it is in arrears in mines where it is stored. Yet mines continue mining, as the downtime can reduce remunerations and cause strikes.

In addition, the Polish government-under the pressure from mining trade unions-decided that some state-owned companies from the energy sector would buy more expensive coal from Polish mines. As a result, cheaper coal from Australia or Russia will not be purchased by the Polish energy sector. The problem is to restore profitability to its own mines and the price of $\mathrm{CO}_{2}$ emission allowances. $\mathrm{CO}_{2}$ emissions are a big problem in Poland, which is further compounded by ineffective waste management. When creating energy policy of the state, one should remember that sustainable waste management can reduce $\mathrm{CO}_{2}$ emissions [1,2]. The years 2018-2019 caused a strong increase in the prices of $\mathrm{CO}_{2}$ emission allowances. This is bad news for the Polish energy sector, as its foundation is energy from coal. High prices of $\mathrm{CO}_{2}$ emission allowances result in a decline in the price of electricity, which in turn, will affect not only individual customers, but above all, Polish enterprises and industry, especially the energy-intensive one. In addition, the energy-consuming industry very often emits significant amounts of $\mathrm{CO}_{2}$ in steelworks, thus becoming a victim of the costs associated with its emission allowances. The Polish energy sector is facing serious challenges. From year-to-year high demand for energy and an increase in the share of coal in energy production is a strategy that must be abandoned. The share of renewable sources should be promoted and increased at all levels, or in the case of large enterprises, small or micro ones-as well as retail customers [3-5]. Though in 2018, the share of renewable sources in final energy consumption increased in Poland, it is still far from the assumptions of the European Union policy. Renewable energy sources (RES) are enjoying an increasing interest, both on the global scale and $\mathrm{n}$ the European Union (EU-28) [6-10]. Research conducted around the world clearly indicates that renewable energy sources (RES) may reduce the European Union (EU)'s dependence on foreign energy supplies and are primarily intended to combat climate change [11]. In addition, the International Energy Agency emphasized the importance of promoting clean energy worldwide, pointing out that the development of this industry had the positive impact on the creation of jobs [12].

The map (Figure 1) presents the share of renewable sources in electricity production in 2018 in selected European countries. Norway is the absolute leader, as the level of electricity produced from renewable sources exceeds total consumption. As one can see, in Poland-as in other countries of Central and Eastern Europe-this indicator is rather low.

The structure of obtaining energy from renewable sources in Poland is primarily connected to the geographical conditions characteristic for Poland and the resources that can be managed. Energy obtained from renewable sources in Poland comes predominantly from solid biofuels, wind energy and liquid biofuels. The details are presented in Table 1. 


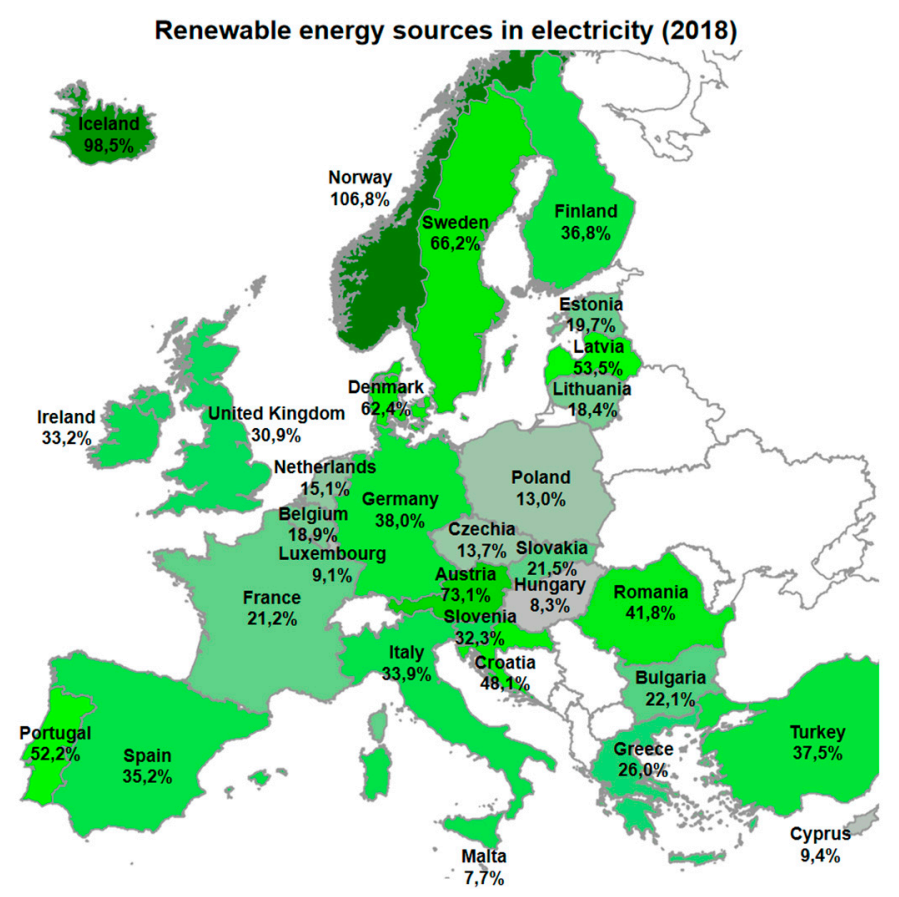

Figure 1. Share of renewable sources in electricity production in 2018 in selected European countries. Source: author's study based on Eurostat databases.

Table 1. Structure of obtaining energy from renewable sources in Poland by carriers 2014-2018.

\begin{tabular}{cccccc}
\hline \multirow{2}{*}{ Renewable Source } & \multicolumn{5}{c}{ Share in the Total Structure } \\
\cline { 2 - 6 } & $\mathbf{2 0 1 4}$ & $\mathbf{2 0 1 5}$ & $\mathbf{2 0 1 6}$ & $\mathbf{2 0 1 7}$ & $\mathbf{2 0 1 8}$ \\
\hline Solid biofuels & 76.13 & 74.24 & 70.78 & 67.87 & 69.26 \\
Wind energy & 8.13 & 10.51 & 11.94 & 14.01 & 12.40 \\
Liquid biofuels & 9.18 & 9.10 & 10.37 & 10.03 & 10.3 \\
Biogas & 2.56 & 2.58 & 2.88 & 3.07 & 3.25 \\
Water energy & 2.31 & 1.77 & 2.03 & 2.40 & 1.91 \\
Municipal waste & 0.45 & 0.45 & 0.67 & 1.01 & 1.11 \\
Solar power & 0.44 & 0.56 & 0.69 & 0.75 & 0.93 \\
Heat pumps & 0.55 & 0.55 & 0.58 & 0.62 & 0.67 \\
Geothermal energy & 0.25 & 0.24 & 0.25 & 0.25 & 0.27 \\
\hline
\end{tabular}

Source: author's study based on Energy from renewable sources in 2018. Statistical analyses. Statistics Poland [13].

Thus, it is clear that in Poland that there is an increase in the production of energy from renewable sources. The growth of SMEs in the trade of equipment and systems for obtaining energy from renewable sources has the significant impact on this growth. Very often these companies-especially small ones-are strongly connected with the construction industry. This industry, in turn, is a leader in Poland when it comes to company failures and bankruptcies [14]. Often, the financial problems of the main investor cause payment bottlenecks, of which SMEs are generally the "victims" [15-17]. It is also caused by the fact that in these units the length of the cash conversion cycle (CCC) is low. They are unable to find an adequate level of net working capital that would ensure their business continuity. There are many different financial management strategies that can improve the financial security of enterprises. One of the popular solutions used around the world and in virtually every sector are multi-entity organizations, referred to as GPOs [14]. For small and medium enterprises in Poland operating in a new sector such as renewable energy, acting together within industry purchasing groups seems to be a very good solution allowing them to function in the event of payment bottlenecks or other disasters. Therefore, the aim of the article is to find an answer to the research question: Is it 
financially more secure for renewable energy companies to operate within purchasing groups than for companies operating alone in the sector?

Poland is currently a country where the share of renewable energy in the total energy consumption structure is decreasing. In the years 2014-2017, the production of electricity from renewable energy sources was gradually increasing, and in 2018 there was a decrease compared to the year: 2015 by $4.7 \%, 2016$ by $5.2 \%, 2017$ by $10.4 \%$. In 2019 , this trend did not change. The negative trend of the decrease in the share of renewable energy in total energy consumption causes certain difficulties in the functioning of current enterprises related to the renewable energy industry, as well as in the creation of new ones. This makes scientists in Poland take actions aimed at improving the security of functioning of renewable energy enterprises. This article is part of the current of this research.

\section{Literature Review}

\subsection{Impact of Purchasing Groups}

Bad management and unskilled staff are important factors which often cause bankruptcies of enterprises [17-20]. Baldwin also confirms that weakness of management was the main reason for bankruptcies of enterprises in Canada [21]. To improve financial liquidity management and security of micro and SMEs operations, enterprises try to combine and organize purchases together [22].

The purchases in relatively small and intensive groups are becoming increasingly popular in both private and public sectors [23-26]. A group purchasing organizations (GPO) can be defined as a group of enterprises from the same or another sector that combine to make joint purchases $[27,28]$. The group purchasing organization is a group of cooperating enterprises that jointly controls and improves material, information and cash flows from suppliers to final recipients. Participants of such a system form a separate central unit whose main task is to achieve the goals set by enterprises operating in a given system [29].

GPOs are a very good model leading to an increase in the bargaining power of enterprises by consolidating the purchasing power of all group members [30-33]. As suggested by Adobor and McMullen [33], the group purchasing organization can be seen as an external entity that facilitates relations between buyers and suppliers. GPOs often promise their customers-by default or explicitly-a lower price through the consolidation of purchases, while reducing the administrative costs resulting from duplication of activities, such as finding suppliers and choosing suppliers in individual categories of products [34,35].

GPOs are created basically in every sector, most of them in the medical sector and the construction industry. In recent years, they have attracted considerable attention because new GPOs have begun to dominate the purchase of pharmaceuticals and other medical products [36]. They also appear in manufacturing companies, as exemplified by the vaccine industry where groups known as VPG are formed. The biggest benefits that VPGs get are lower initial costs, e.g., launching a given vaccine line [37].

One should remember that the main factor that guarantees the success of a purchasing group is the trust of individual members operating in such a group. This is one of the most-discussed factors for GPO success [38-40]. Lack of trust among co-holders of the group is the first key signal that such an organization will not be able to use its purchasing power $100 \%$.

In recent years, there has been criticism of members of many purchasing groups [41,42] or the opposite situation, where group managers complained that members of a given group did not comply with the recommendations taken on their behalf by the managing representative of the entire GPO [43].

It is very important to have a clearly defined action strategy connecting all participants of the group [44,45]. Therefore, a good solution is to operate within the GPOs where the effect of scale is not broken down and companies operating in the group can also cooperate. Typical advantages of a cooperative purchase are lower prices, higher quality, lower transaction costs, less workload, less risk (supply) and mutual learning, improving wealth management efficiency, joint information 
processing [46-54]. Typical disadvantages are configuration costs, coordination costs, loss of flexibility, loss of control, supplier resistance and possible interference in antitrust legislation [55].

Group purchasing was already known in ancient Babylon [56]. Despite its long history, cooperative purchasing was not and continued to be of little interest in social sciences [27,57-59]. Lack of interest in research seems unjustified, and joint purchases are more well-established in practice $[22,25,38,55,60,61]$. However, the sector in which they appear the most is the health care sector [62]. Many of these types of organizations are also created in the pharmaceutical, food, construction and aerospace industries. In the literature one can find much theoretical information on joint purchasing strategies and classification of purchasing groups $[25,63,64]$. However, there is clearly a lack of studies on SMEs operating $h$ in industry purchasing groups.

In the literature, one can find many results of research on units operating in GPOs generally associated with the health care industry $[21,22,25]$. In the medical sector, companies must publish their financial statements, which definitely facilitates access to financial data. In turn, the big problem limiting SME research in Poland is the difficult access to such reports. In Poland, SMEs should submit their reports to the National Court Register, in practice, often these reports are missing or incomplete. The analysis of SMEs operating in the renewable energy sector is therefore a research gap. The functioning of units related to healthcare in GPO is primarily intended to reduce costs, increase profits and not to regulate the level of financial liquidity. The situation is different in the case of the construction industry, and above all in the renewable energy sector developing in Poland, where the most important task is to design a secure financial policy for enterprises.

Therefore, the choice of the industry particularly at risk of bankruptcy of the first SME group operating in it constitutes a new look at the functioning of purchasing groups in the aspect of financial security.

\subsection{Purchasing Groups and Their Functioning}

There are many classifications of purchasing groups, which divide them primarily into sector and general ones. In turn, other authors extract "five forms of cooperative purchasing are discussed," The five forms are called [63]:

- Piggybacking groups. Piggybacking groups are informal GPOs that focus on the simplest cooperation possible. In some cases, this form of cooperative purchase involves only sharing information;

- Third-party groups. Third-party groups mostly involve long term piggybacking made possible by public or private external parties or central authorities with devoted resources. The third party is a for-profit organization or a non-profit organization and may be owned by the members of the group;

- Lead buying groups. A leading purchasing group includes outsourcing of purchasing activities to one of the other members of the group: each element is purchased by the most appropriate organization or external entity according to their specialist knowledge, resources or volume of purchases;

- Project groups. The group is an intensive form of cooperative purchase. Typically, a project group is a one-time purchase group for a joint purchasing project. The members of the group join forces once and together they make purchases. A project group is an intensive form of cooperative purchasing. Typically, a project group is a one-time purchasing group for a shared purchasing project;

- Program groups.

For the sector GPOs a model based on the third-party groups is applied. Using this purchasing model for Polish GPOs, it is assumed to create the central unit that manages the group. In Poland, the GPOs usually operate in this way. In the case of commercial companies operating in the renewable energy sector this is a safe option as it can also be supported by the central warehouse. The central warehouse is created by the group's central unit. It allows storing excess inventory, which with an 
additional margin is resold if necessary to individual participants of a given group. When using a central warehouse, there are several additional options for organizing deliveries [23].

All companies, regardless of the sector, need cash to grow [65]. In case of enterprises operating in the energy industry, the authors state that the development of this sector is most often limited by the lack of resources, technology complexity, climate change, climate policy, lack of qualified personnel, lack of knowledge and experience in marketing and communication. [66-68]) There are authors who believe that the development of this sector is limited by the lack of know-how technology [69-72]. Many of these barriers may be eliminated due the cooperation in the framework of multi-stakeholder organizations referred to group purchasing organizations. This is obviously caused by the use of economies of scale, but also by the cooperation of individual enterprises within the group, which allows using the benchmarking tools or even loans to co-organizers of a given group

Today's example of the COVID-19 pandemic clearly indicates that multi-stakeholder organizations-especially those that use the central warehouse-are and will be able to operate longer than companies operating alone in the market. Since in case of problems of one participant of the purchasing group, it is possible to transfer employees, inventories to "healthy" functioning units. On the other hand, financial assistance (extended trade credits, loans) can be launched immediately to keep the company in the market before government support for such units is approved and implemented [23].

It is worth remembering that in case of the central unit, an important element securing the functioning of the entire group is the division of the management team into two, as in case of excluding one team from operation, the other unit deals with the ordering and distribution process. It is a solution that does not require large expenditure and introduces additional security that will extend the functioning of the entire group.

\section{Materials and Methods}

\subsection{Data}

The research was conducted on a group of Polish commercial SMEs operating in the renewable energy industry. In Poland, the first purchasing groups were created in the construction industry, and they currently have a very strong position in the Polish market and are an example of multi-entity organizations. To date, there are 3 purchasing groups (GPO) of 54 enterprises operating in the renewable energy industry. Enterprises were divided into two groups, into units operating in multi-entity organizations and into the ones operating alone in the market, i.e., those that do not operate within multi-entity organizations. The analysis concerns 64 companies, of which 42 were operating in GPOs, and 22 were independent units. Financial ratios were calculated on the basis of financial statements for 2015-2018. The primary goal of the analysis is to compare selected financial indicators between both groups.

\subsection{Methods}

Statistical methods used for statistical analyses were selected according to the research problems considered in the work [73-75]. The comparative characteristics of enterprises from both groups was based on a set of descriptive statistics (mean, median, standard deviation as well as minimum and maximum) for selected financial indicators of companies from the groups compared. The Mann-Whitney test was used to assess the significance of differences in the level of selected indicators in both groups - the choice of a nonparametric test was dictated by the lack of normality in the distribution of financial indicators in the compared groups.

To examine the relationship between various groups of financial indicators, correlation coefficient matrices were determined, illustrating selected results using scatter plots. The correlation analysis was performed taking into account the division of enterprises into both compared groups. 
Finally, in order to determine the impact of the rotation of receivables, liabilities and inventories on financial liquidity, a regression model was created. The regression model also includes membership in the GPO or independent enterprises, and interactions between membership in the GPO and rotation indicators, which leads to the model of the form:

$\mathrm{FL}=\beta_{0}+\beta_{1} \cdot \mathrm{GPO}+\beta_{2} \cdot \mathrm{RTR}+\beta_{3} \cdot \mathrm{LTR}+\beta_{4} \cdot \mathrm{ITR}+\beta_{5} \cdot \mathrm{GPO} \times \mathrm{RTR}+\beta_{6} \cdot \mathrm{GPO} \times \mathrm{LTR}+\beta_{7} \cdot \mathrm{GPO} \times \mathrm{ITR}+\varepsilon$

In the above equation, FL denotes financial liquidity, GPO denotes dichotomous variable, defining belonging to a GPO (value 1) or a group of independent enterprises (0), RTR denotes receivables turnover ratio, LTR-liabilities turnover ratio, ITR-inventory turnover ratio and GPO $\times$ RTR, GPO $\times$ LTR and $\mathrm{GPO} \times$ ITR denotes interactions between GPO and rotations.

\section{Results}

Based on our analyses, it can be concluded that in the purchasing group compared to independent companies, we have a significantly higher level of profitability (median $4.10 \%$ in the purchasing group vs. $1.25 \%$ among independent companies), significantly higher liquidity (2.86 vs. 1.35$)$ and a longer cycle (83 vs. 46 days). All these differences were highly reliable, the $p$ value determined using the Mann-Whitney test was below 0.001 . There were no significant differences in the level of effectiveness, although the difference was close to statistically significant $(p=0.0669)$. The details are presented in Table 2.

Table 2. Statistics on the distribution of financial indicators in both groups compared.

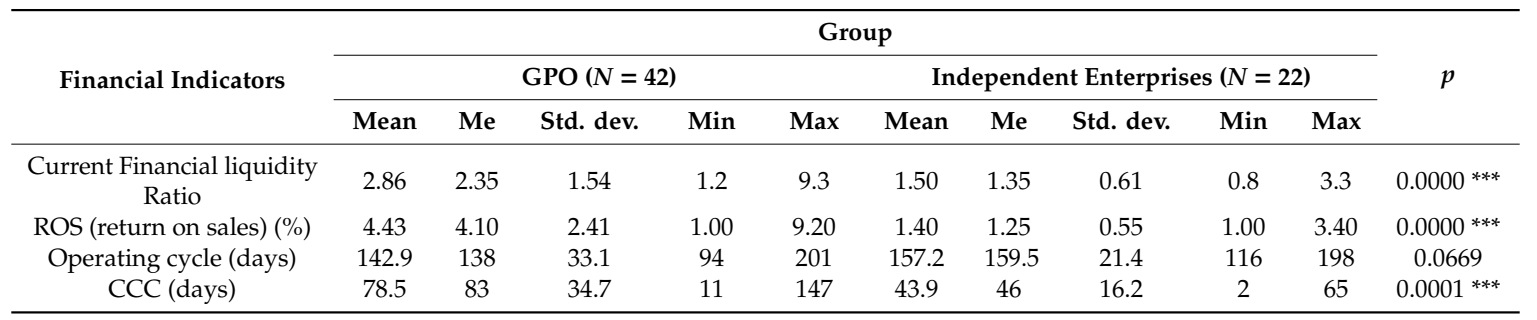

$p$ value calculated using Mann-Whitney test; ${ }^{*}, * *$ and ${ }^{* * *}$ denotes statistical significance of difference between groups (respectively at level $p<0.05 ; p<0.01$ and $p<0.001$ ); Source: author's calculations and studies.

The charts (Figure 2) show the values of positional statistics and the exact distribution of the values of current financial liquidity ratio and ROS (return on sales) in the compared groups.
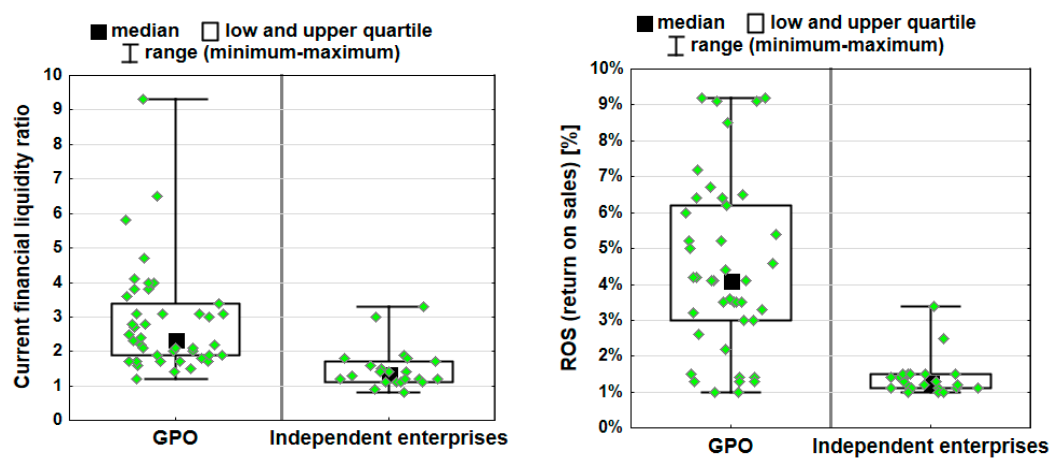

Figure 2. Positional statistics for financial liquidity and profitability in the compared groups. Source: author's calculations and studies.

Thus, it can be seen that the indicators and results presented in Table 2 and Figure 2 are clearly more favorable in enterprises operating in GPOs.

The share of inventories and receivables from customers in both groups of enterprises was compared in an analogous way. There are no grounds to establish differences in the level of these two 
indicators between independent enterprises and GPOs affiliated enterprises. The values of positional measures (means and medians) are almost identical in both groups, and the lack of statistically significant differences was verified using the Mann-Whitney test ( $p$ values definitely exceed 0.05). The details are presented in Table 3.

Table 3. Statistics on the distribution of current assets share ratios in both compared groups.

\begin{tabular}{|c|c|c|c|c|c|c|c|c|c|c|c|}
\hline \multirow{3}{*}{ Financial Indicators } & \multicolumn{10}{|c|}{ Group } & \multirow{3}{*}{$p$} \\
\hline & \multicolumn{5}{|c|}{ GPO $(N=42)$} & \multicolumn{5}{|c|}{ Independent Enterprises $(N=22)$} & \\
\hline & Mean & Me & Std. dev. & $\min$ & $\max$ & Mean & $\mathrm{Me}$ & Std. dev. & $\min$ & $\max$ & \\
\hline $\begin{array}{l}\text { Share of receivables } \\
\text { in current assets }(\%)\end{array}$ & 44.1 & 45.5 & 9.5 & 23.0 & 70.0 & 42.3 & 44.5 & 7.5 & 23.0 & 57.0 & 0.3723 \\
\hline $\begin{array}{l}\text { Share of inventory in } \\
\text { current assets }(\%)\end{array}$ & 49.5 & 51.0 & 9.5 & 28.0 & 61.0 & 52.5 & 53.0 & 5.9 & 40.0 & 63.0 & 0.4193 \\
\hline
\end{tabular}

$p$ value calculated using Mann-Whitney test. Source: author's calculations and studies.

Another research goal was to verify which of the factors-inventory turnover, receivables from customers or payables to suppliers influence the results of current assets management efficiency (operating cycle). For this purpose, Spearman's rank correlation coefficients between efficiency and the three indicators mentioned above were determined. The analysis was carried out separately for both groups of companies, presenting charts in a summary table (Table 4) and selected results were presented on scatter charts (Figure 3). As can be seen, in the GPO group all "rotations" are correlated with efficiency, except that the receivables turnover is most strongly ( $R=0.85$ among GPO companies and $R=0.72$ among independent companies). No statistically significant correlation exists between the efficiency and rotation of liabilities in the GPO group $(R=0.28)$. Due to the specific nature of the efficiency measure (operating cycle length), one can conclude from the analysis that the extension of rotation cycles (especially receivables and inventory) is associated with an increase in the operating cycle length, i.e., a decrease in efficiency.

Table 4. Correlations between operating cycle and receivables, liabilities and inventory turnover ratios (Spearman's rank coefficient of correlation with result of significance test).

\begin{tabular}{|c|c|c|}
\hline \multirow{3}{*}{ Turnover Ratios (Days) } & \multicolumn{2}{|c|}{ Group } \\
\hline & GPO & Independent Enterprises \\
\hline & \multicolumn{2}{|c|}{ Operating Cycle (Days) } \\
\hline Receivables & $0.85\left(p=0.0000^{* * *}\right)$ & $0.72\left(p=0.0002^{* * *}\right)$ \\
\hline Liabilities & $0.28(p=0.0755)$ & $0.67\left(p=0.0006^{* * *}\right)$ \\
\hline Inventory & $0.55\left(p=0.0002^{* * *}\right)$ & $0.83\left(p=0.0000^{* * *}\right)$ \\
\hline
\end{tabular}

$*, * *$ and ${ }^{* * *}$ denotes statistical significance of correlation between variables (respectively at level $p<0.05 ; p<0.01$ and $p<0.001)$. Source: Own calculations and studies.

Below there are presented the selected relationships in the form of scatter diagrams (Figure 3).

The correlations between the profitability level of companies from both groups and selected indicators - effectiveness, share of receivables and inventories and credit position were also examined. It is interesting that statistically significant correlations occur only in the GPO group (Table 5). Profitability is positively influenced by having a larger share of receivables $(R=0.40)$ and credit position $(R=0.50)$ and negatively a larger share of inventories $(R=-0.61)$. There is no relationship between profitability and efficiency. The reason for the lack of correlation in the group of independent companies may be the fact that the level of profitability in this group is low and very even, so it is difficult to find factors that differentiate it. 

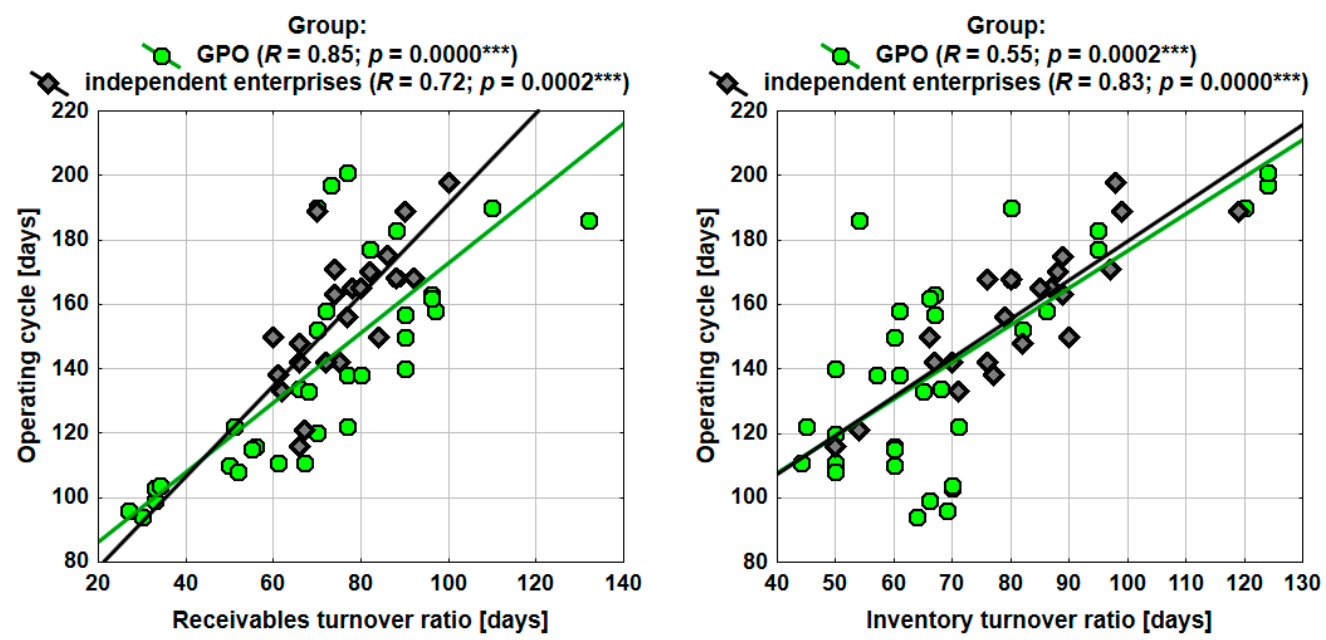

Figure 3. Scatter chart of receivables and inventory turnover cycles. Source: author's calculations and studies.

Table 5. Spearman's rank coefficient of correlation between the profitability level of companies from both groups and the selected indicators-efficiency, share of receivables and inventory and credit position (with result of significance test).

\begin{tabular}{ccc}
\hline \multirow{2}{*}{ Financial Indicators } & GPO & $\begin{array}{c}\text { Group } \\
\text { Independent Enterprises } \\
\text { ROS (Return on Sales) (\%) }\end{array}$ \\
\cline { 2 - 3 } & $0.40\left(p=0.0094^{* *}\right)$ & $-0.04(p=0.8450)$ \\
Share of receivables in current assets $(\%)$ & $0.02(p=0.9360)$ \\
Share of inventory in current assets $(\%$ & $-0.61\left(p=0.0000^{* * *}\right)$ & $-0.15(p=0.5151)$ \\
Credit position & $0.50\left(p=0.0007^{* * *}\right)$ & $0.03(p=0.8851)$ \\
Operating cycle (days) & $0.14(p=0.3900)$ & (2)
\end{tabular}

Source: author's calculations and studies. ${ }^{*}, * *$ and ${ }^{* * *}$ denotes statistical significance of correlation between variables (respectively at level $p<0.05 ; p<0.01$ and $p<0.001$ ).

The selected relationships are presented in the form of scatter diagrams (Figure 4).
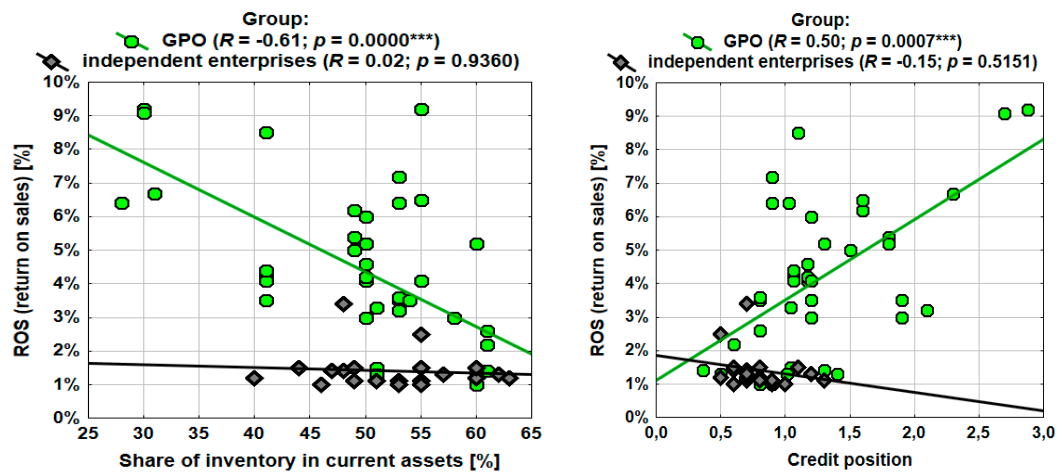

Figure 4. Graph of the relationship between the profitability level and the credit position and the share of inventories in current assets. Source: author's calculations and studies

The next step was to examine the rates of rotation of receivables from customers, stocks and liabilities to suppliers. They belong to the group of indicators of effectiveness of company management. They provide information on how well a company is managed, but most importantly they provide much important information on the financial security of companies, especially those belonging to SMEs. Table 6 presents the results of the indicators of receivables from customers, inventories and payables to suppliers in days. 
Table 6. Statistics on the distribution of financial indicators in both groups compared.

\begin{tabular}{|c|c|c|c|c|c|c|c|c|c|c|c|}
\hline \multirow{3}{*}{$\begin{array}{c}\text { Financial } \\
\text { Indicators (days) }\end{array}$} & \multicolumn{10}{|c|}{ Group } & \multirow{3}{*}{$p$} \\
\hline & \multicolumn{5}{|c|}{ GPO $(N=42)$} & \multicolumn{5}{|c|}{ Independent Enterprises $(N=22)$} & \\
\hline & Mean & Me & Std. dev. & Min & $\operatorname{Max}$ & Mean & Me & Std. dev. & Min & Max & \\
\hline $\begin{array}{l}\text { Receivables } \\
\text { turnover ratio }\end{array}$ & 72.1 & 71 & 25.3 & 27 & 132 & 75.9 & 74.5 & 10.9 & 60 & 100 & 0.5794 \\
\hline $\begin{array}{l}\text { Liabilities } \\
\text { turnover ratio }\end{array}$ & 63.7 & 62 & 24.6 & 21 & 127 & 113.4 & 117 & 24.9 & 68 & 154 & $0.0000^{* * *}$ \\
\hline $\begin{array}{l}\text { Inventory } \\
\text { turnover ratio }\end{array}$ & 70.5 & 67 & 18.9 & 44 & 124 & 81.3 & 81 & 15.5 & 50 & 119 & $0.0026^{* *}$ \\
\hline
\end{tabular}

$p$ value calculated using Mann-Whitney test, ${ }^{*}, * *$ and ${ }^{* * *}$ denotes statistical significance difference between groups (respectively at level $p<0.05 ; p<0.01$ and $p<0.001$ ).

Based on the calculations presented in Table 6, no statistically significant differences in the length of the receivable turnover were found, while for the other two indicators, significantly higher values were observed in the group of independent companies. The average duration of the liabilities turnover in independent companies was by more than 50 days (113.4 vs. 63.7), and inventories by more than 10 days (81.3 vs. 70.5 ) longer than in companies associated in GPO.

These results indicate more efficient inventory management in the group of companies operating in the GPO, which has the large impact on the financial security of the companies. A large share of inventories in the structure of current assets adversely affects liquidity. Overdrawing of inventories in warehouses causes an increase in costs, which also negatively affects the profitability of units.

When analyzing the results from Table 6, it can be seen that the companies operating in the GPO try to quickly settle their liabilities to suppliers. This is a clear indication of their strength. To a large extent, this is due to the fact that the central unit, when negotiating with the producer, often obtains the possibility to receive an additional discount for an early payment. It often takes advantage of this, which results in a relatively low rate of rotation of liabilities in days. In the case of companies operating on their own, such opportunities rarely occur. When analyzing table and liquidity ratios, it can be seen that these companies have problems with settling their liabilities on time.

Figure 5 presents positional statistics for liabilities and inventory turnover ratio in the compared groups.
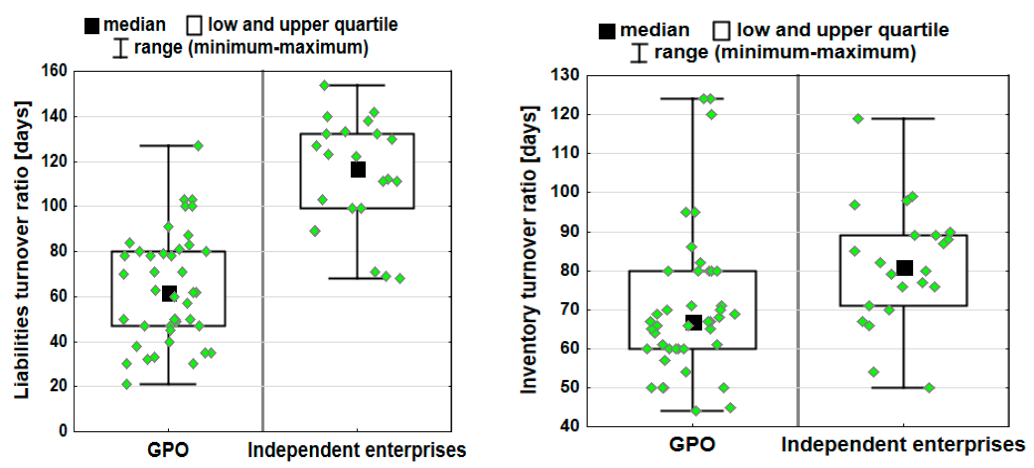

Figure 5. Positional statistics for liabilities and inventory turnover ratio in the compared groups.

Source: author's calculations and studies.

The aim of the next stage of data analysis was to determine whether the turnover of liabilities, receivables and inventories affects the company's liquidity and whether this influence depends on whether it operates independently or in GPO. The earlier analyses showed that the liquidity was significantly higher among companies with GPO.

In order to determine the nature of the impact of the length of financial turnovers and membership in GPOs on the level of financial liquidity, a regression model was constructed. The dependent variable in this model was financial liquidity, while independent variables: length of receivables, liabilities, inventories turnovers and a dichotomous factor-GPO affiliation. Additionally, interactions between 
GPO membership and the length of turnovers of receivables, liabilities and inventories were taken into account.

The model describes the variability of financial liquidity in the studied group of companies to a fairly good degree (the determination coefficient $R^{2}$ is about $65 \%$ ). Statistically significant factors are GPO membership, liability turnover, inventory turnover. The turnover of receivables does not affect the companies' liquidity. The interaction between GPO membership and the turnover of liabilities is also statistically significant. Based on the value of model coefficients (B), the type of relationship between individual factors and the level of liquidity can be specified:

- GPO companies have, on average, 3.510 more liquidity than stand-alone companies with the same receivables, liabilities and inventory turnover

- the extension of the liability turnover by one day, results in a 0.033 decrease in liquidity

- the significance of the interaction between the GPO membership and the liability turnover allows to conclude that the relationship between the liability turnover and liquidity is greater in this group (adjusted coefficient -0.052) than in the group of stand-alone companies (adjusted coefficient -0.014 )

- the extension of the inventory turnover by one day translates into an increase in liquidity by 0.019 .

Based on the value of the standardized regression factor $(\beta)$, it is possible to assess the strength of the influence of individual factors on the level of liquidity. When comparing the absolute values of the $\beta$ coefficient, it can be concluded that the interaction of the liability level with the company's GPO membership and the fact of being a GPO member is crucial (Table 7).

Table 7. Results for regression model with current financial liquidity ratio as dependent variable.

\begin{tabular}{|c|c|c|c|}
\hline \multirow{2}{*}{ Effects } & \multicolumn{3}{|c|}{$\begin{array}{l}\text { Current Financial Liquidity Ratio } R^{2}=64.9 \% ; \\
\qquad F=37.0 ; p=0.0000 * * *\end{array}$} \\
\hline & $B$ & $p$ & $\beta$ \\
\hline Group (GPO vs. independent) & 3.510 & $0.0351 *$ & 1.160 \\
\hline Receivables turnover ratio & 0.010 & 0.3512 & 0.155 \\
\hline Liabilities turnover ratio & -0.033 & $0.0000^{* * *}$ & -0.785 \\
\hline Inventory turnover ratio & 0.019 & $0.0328 *$ & 0.240 \\
\hline Group $\times$ receivables turnover ratio & 0.015 & 0.1841 & 0.766 \\
\hline Group $\times$ liabilities turnover ratio & -0.019 & $0.0046^{* * *}$ & -1.173 \\
\hline Group $\times$ inventory turnover ratio & -0.016 & 0.0759 & -0.805 \\
\hline
\end{tabular}

$B$-regression coefficient, $p$-assessment of statistical significance, $\beta$-standardized regression coefficient, ${ }^{*}, * *$ and *** denotes statistical significance of effects or whole model (respectively at level $p<0.05 ; p<0.01$ and $p<0.001$ ).

\section{Managerial Insights}

1. The research shows a recommendation that in order to improve the profitability of companies in the renewable energy sector, they should join purchasing groups;

2. The significant difference between the profitability of running a business within a purchasing group and an independent one indicates that operating within a purchasing group increases the financial security of each renewable energy company participating in it;

3. Managers can control stocks, receivables and liabilities in the manner indicated in the surveys. The variable to be considered the most difficult to manage are receivables, as it is the customers who decide on the actual payment date. Therefore, it is recommended to pursue a consistent pricing policy with respect to customers, aimed at increasing sales and current control and effective enforcement of receivables payments by customers. As far as stock optimization is concerned, it is advisable for renewable energy companies to use a central warehouse when creating a new purchasing group. All the examined renewable energy companies that belong to purchasing groups used such a warehouse; 
4. Proper management of stocks, receivables and liabilities is crucial to increase the financial security of renewable energy companies. The research shows that the effectiveness of management of these variables is higher in renewable energy companies that operate in purchasing groups, which indicates another reason for renewable energy companies to associate into purchasing groups.

\section{Discussion and Conclusions}

In the literature, one can find much information where the authors confirm that acting within purchasing groups allows reducing a number of costs, increasing profitability, improving financial liquidity [76-79].

The literature indicates that so far the most common purchasing groups were organized in the medical sector around the world and in the construction industry.

The analysis concerns SMEs operating in the renewable energy sector, which is developing in Poland. At the same time, Poland is a country where the political decisions of the government over the last few years have resulted in a significant reduction of the possibilities of renewable energy development. The development of renewable energy in Poland was quite dynamic in the years 2012-2016. However, since 2017 it has been severely hampered by unfavorable legal regulations, which have significantly limited investments in the renewable energy market. The dynamics of renewable energy development in Poland is presented in Figure 6.

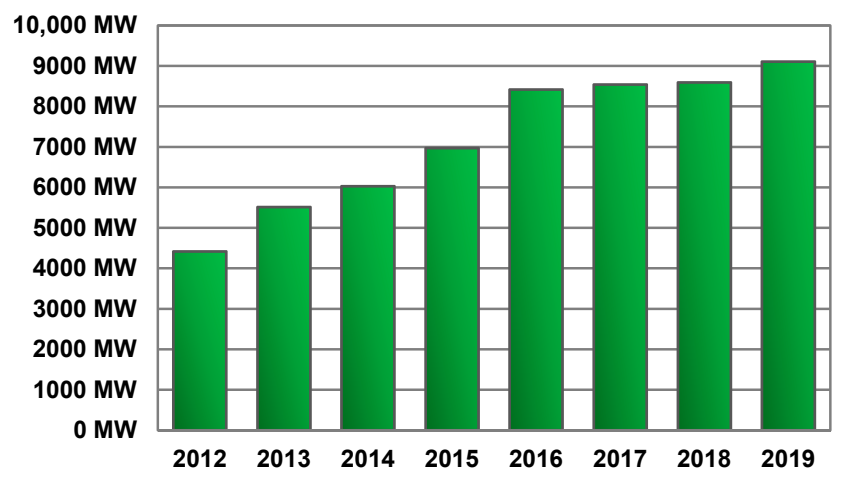

Figure 6. Renewable energy power (MW) in Poland. Source: Energy Regulatory Office (as of 31.12.2019).

These measures have also resulted in a decrease in the profitability of the current renewable energy companies, especially those from the small and medium-sized enterprise sector. At the end of 2020, the European Union set Poland a target of $15 \%$ share of renewable energy consumption. This target will not be reached by Poland. A real salvation from the high penalties that the European Union may impose on Poland for not meeting this target are investments undertaken by micro producers and renewable energy enterprises in the SME sector. The minimal increase of renewable energy capacity in Poland in 2019 is due to the development of photovoltaic systems supported by European Union aid. Geothermal energy has also potential opportunities [80]. The research shows that currently Poland is among the weakest EU countries in the share of renewable energy consumption [81-83]. Focusing the development of renewable energy in Poland on micro-producers provides new opportunities for the development of SMEs operating in the renewable energy sector.

The aim of the article - and at the same time the research question — was whether the operation of renewable energy enterprises within purchasing groups is financially safer in relation to enterprises operating independently in this industry. The research confirms the results of research conducted so far in the medical sector and construction industry and at the same time indicates that renewable energy companies can also improve their profitability and thus the possibility of a safe continuation of their operations by extending the business model of operation to inter-company cooperation within purchasing groups. The statistical analysis and their graphic presentation present the significant impact on the safety and profitability of renewable energy entities in the form of purchasing groups. 
On the basis of the conducted research, the conclusions can be drawn:

1. Renewable energy companies operating in groups obtain higher liquidity, a cash conversion cycle (CCC) and profitability;

2. The operating cycle should also be assessed positively, as the average performance and median results in the entities operating in groups are lower than those of stand-alone companies. In a situation where enterprises operating in groups have obtained higher liquidity, the results of the operating cycle should be lower than those of stand-alone entities;

3. Renewable energy companies operating in purchasing groups are better at managing their stocks than those operating independently. The main reason for this is the use of the central warehouse by renewable energy companies operating in purchasing groups. The research shows that the share of inventories in current assets is lower in enterprises operating in purchasing groups;

4. The studies also show that acting in a purchasing group, by exploiting economies of scale, allows renewable energy companies to negotiate favorable repayment terms with suppliers. Shorter cycles of liabilities rotation in companies operating in purchasing groups prove higher financial liquidity. It also means greater financial security for renewable energy enterprises operating in purchasing groups than enterprises operating independently;

5. The research has also shown that the profitability of renewable energy enterprises is significantly influenced by a larger share of receivables in the asset structure and the level of credit position in relation to enterprises operating independently. Better financial condition of enterprises operating in purchasing groups allows extending the cycle of receivables rotation, which is an important motivator encouraging customers to increase purchases in these enterprises. These actions also increase the profitability of conducting business activity by renewable energy enterprises operating in purchasing groups in relation to those enterprises which operate independently.

In the future, a larger proportion of companies operating in the renewable energy sector should be covered by this study. The demand for renewable energy will continue to grow, which should be seen as an incentive for further research. Although the world's energy demands have decreased significantly in the early 2020 period, this trend is unlikely to continue in the long term. This uncertainty is linked to the pandemic and the speed at which the world economy is recovering from before the outbreak. However, it must be recognized that the share of renewable energy consumption in the energy consumption structure will continue increasing. Poland is in a specific period of its operation, which may, although should not, have the impact on research results. For this reason, this type of research should be extended in the future to other European Union countries as well.

Due to their nature, the results of these studies can probably be implemented in any country. There is much evidence-both in theory and in practice - that cooperation promotes synergies [68]. The prerequisite for the implementation of renewable energy purchasing groups in a given country is a similar share of renewable energy in total energy. A similar share as Poland has several European Union countries. The share (\%) in selected countries is presented in Figure 7.

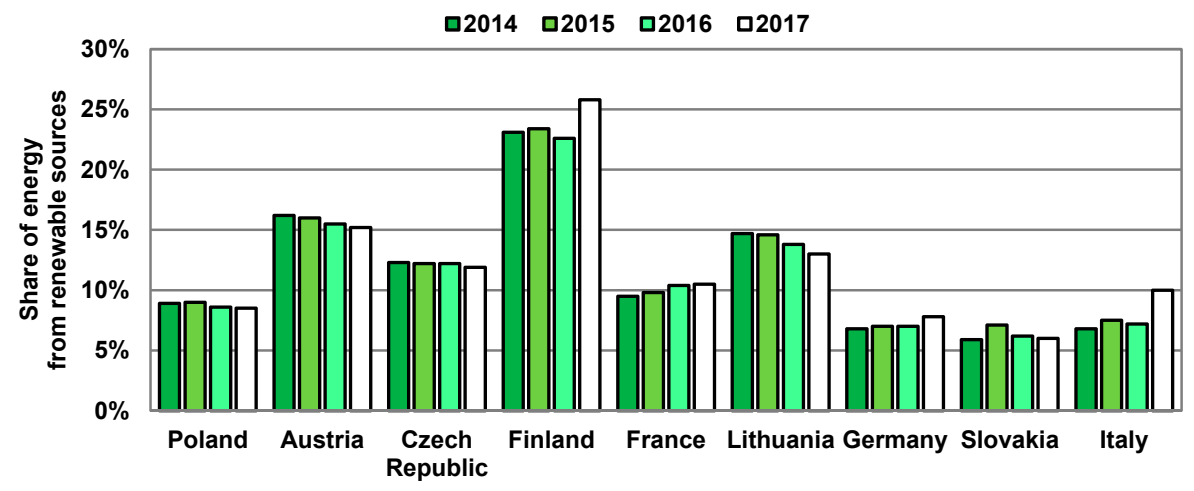

Figure 7. Share of energy from renewable sources in final consumption [13]. 
Due to similar market and entrepreneurial developments, this would be possible especially in Central and Eastern European countries. However, additional studies are needed to confirm this statement.

Author Contributions: Conceptualization, G.Z., M.S. and G.L.; writing-original draft preparation, G.Z., G.L; formal analysis, G.Z., G.L and M.S., writing-review and editing, G.Z and G.L; visualization, M.S.; funding acquisition, G.Z., M.S. and G.L. All authors have read and agreed to the published version of the manuscript.

Funding: This research received no external funding.

Conflicts of Interest: The authors declare no conflicts of interest.

\section{References}

1. Cucchiella, F.; D'Adamo, I.; Gastaldi, M. Future trajectories of renewable energy consumption in the European Union. Resources 2018, 7, 10. [CrossRef]

2. Qin, Z.; Zhuang, Q.; Cai, X.; He, Y.; Huang, Y.; Jiang, D.; Lin, E.; Liu, Y.; Tang, Y.; Wang, M.Q. Biomass and biofuels in China: Toward bioenergy resource potentials and their impacts on the environment. Renew. Sustain. Energy Rev. 2018, 82, 2387-2400. [CrossRef]

3. Kurek, K.A.; Heijman, W.; Van Ophem, J.; Geedek, S.; Strojny, J. The impact of geothermal resources on the competitiveness of municipalities: Evidence from Poland. Renew. Energy 2020, 151, 1230-1239. [CrossRef]

4. Simionescu, M.; Strielkowski, W.; Tvaronavičienè, M. Renewable energy in final energy consumption and income in the EU-28 countries. Energies 2020, 13, 2280. [CrossRef]

5. Sowiżdżał, K.; Słoczyński, T.; Sowiżdżał, A.; Papiernik, B.; Machowski, G. Miocene biogas generation system in the carpathian foredeep (SE Poland): A basin modeling study to assess the potential of unconventional mudstone reservoirs. Energies 2020, 13, 1838. [CrossRef]

6. Stolarski, M.J.; Warminski, K.; Krzyzaniak, M. Energy value of yield and biomass quality of poplar grown in two consecutive 4-year harvest rotations in the north-east of Poland. Energies 2020, 13, 1495. [CrossRef]

7. Svazas, M.; Navickas, V.; Krajnakova, E.; Nakonieczny, J. Sustainable supply chain of the biomass cluster as a factor for preservation and enhancement of forests. J. Int. Stud. 2019, 12, 277-288. [CrossRef]

8. Kluts, I.; Wicke, B.; Leemans, R.; Faaij, A. Sustainability constraints in determining European bioenergy potential: A review of existing studies and steps forward. Renew. Sustain. Energy Rev. 2017, 69, 719-734. [CrossRef]

9. Van Meerbeek, K.; Muys, B.; Hermy, M. Lignocellulosic biomass for bioenergy beyond intensive Copland and forests. Renew. Sustain. Energy Rev. 2019, 102, 139-149. [CrossRef]

10. Ozturk, M.; Saba, N.; Altay, V.; Iqbal, R.; Hakeem, K.R.; Jawaid, M.; Ibrahim, F.H. Biomass and bioenergy: An overview of the development potential in Turkey and Malaysia. Renew. Sustain. Energy Rev. 2017, 79, 1285-1302. [CrossRef]

11. Caruso, G.; Colantonio, E.; Gattone, S.A. Relationships between renewable energy consumption, social factors, and health: A panel vector auto regression analysis of a cluster of $12 \mathrm{EU}$ countries. Sustainability 2020, 12, 2915. [CrossRef]

12. Caruso, G.; Gattone, S.A. Waste management analysis in developing countries through unsupervised classification of mixed data. Soc. Sci. 2019, 8, 186. [CrossRef]

13. Energy from Renewable Sources in 2018. Statistical Analyses; Statistics Poland: Warsaw, Poland, 2020; pp. 20-38.

14. Zimon, G. Influence of group purchasing organizations on financial situation of Polish SMEs. Oeconomia Copernic. 2018, 9, 87-104. [CrossRef]

15. Lew, G.; Pacana, A.; Kulpa, W. The concept of customer cost accounting. J. Bus. Retail Manag. Res. 2017, 11, 124-129.

16. Ooghe, H.; Prijcker, D.S. Failure processes and causes of company bankruptcy: A typology. Manag. Decis. 2006, 46, 223-242. [CrossRef]

17. Kontuš, E.; Mihanović, D. Management of liquidity and liquidassets in small and medium-sized enterprises. Econ. Res. Ekon. Istraž. 2019, 32, 3247-3265. [CrossRef]

18. Özbayrak, M.; Akgün, M. The effects of manufacturing control strategies on the cash conversion cycle in manufacturing systems. Int. J. Prod. Econ. 2006, 103, 535-550. [CrossRef] 
19. Asem, E.; Alam, S. Cash hoards and changes in investors' outlook. J. Financ. Res. 2014, 37, $119-137$. [CrossRef]

20. Cicea, C.; Popa, I.; Marinescu, C.; Stefan, S.C. Determinants of SME's performance: Evidence from European countries. Econ. Res. Ekon. Istraž. 2019, 32, 1602-1620. [CrossRef]

21. Baldwin, J.R. Failing Concerns: Business Bankruptcy in Canada, Failing Concerns: Business Bankruptcy in Canada; Statistics Canada: Ottawa, ON, Canada, 1998; pp. 1-72.

22. Nollet, J.; Beaulieu, M. The development of group purchasing: An empirical study in the healthcare sector. J. Purch. Supply Manag. 2003, 9, 3-10. [CrossRef]

23. Zimon, G. organization of transport in a commercial enterprise operating in a branch purchasing group. Estud. Ekon. Apl. 2018, 36, 811-824. [CrossRef]

24. Sandberg, E.; Mena, C. Exploring strategic strengths and weakness of retail purchasing groups. Int. Rev. Retail Distrib. Consum. Res. 2015, 25, 276-297.

25. Nollet, J.; Beaulieu, M. Should an organisation join a purchasing group? Supply Chain Manag. 2005, 10, 11-17. [CrossRef]

26. Polychronakis, Y.; Syntetos, A. 'Soft' supplier management related issues: An empirical investigation. Int. J. Prod. Econ. 2007, 106, 431-449. [CrossRef]

27. Tella, E.; Virolainen, V.M. Motives behind purchasing consortia. Int. J. Prod. Econ. 2005, 93, 161-168. [CrossRef]

28. Zimon, G. Model of the branch purchasing group in the chemical industry. Przem. Chem. 2018, 97, $1808-1810$.

29. Faes, W.; Matthyssens, P.; Vandenbempt, K. The pursuit of global purchasing synergy. Ind. Mark. Manag. 2000, 29, 539-553. [CrossRef]

30. Chipty, T.; Snyder, C.M. The role of firm size in bilateral bargaining: A study of the cable television industry. Rev. Econ. Stat. 1999, 81, 326-340. [CrossRef]

31. Inderst, R.; Wey, C. Buyer power and supplier incentives. Eur. Econ. Rev. 2007, 51, 647-667. [CrossRef]

32. Zimon, D. Impact of the implementation of quality management system on operating cost for small and medium-sized business organizations affiliated to a purchasing group. Int. J. Qual. Res. 2015, 9, 551-564.

33. Adobor, H.; McMullen, R.S. Strategic purchasing and supplier partnership-The role of a third party organization. J. Purch. Supply Manag. 2014, 20, 263-272. [CrossRef]

34. Nollet, J.; Beaulieua, M.; Fabbe-Costes, N. The impact of performance measurement on purchasing group dynamics: The Canadian experience. J. Purch. Supply Manag. 2017, 23, 17-27. [CrossRef]

35. Blair, R.D.; Durrance, C.P. Group purchasing organizations, monopsony, and antitrust policy. Manag. Decis. Econ. 2014, 35, 433-443. [CrossRef]

36. Marvel, H.P.; Yang, H. Group purchasing, nonlinear tariffs, and oligopoly. Int. J. Ind. Organ. 2008, 26, 1090-1105. [CrossRef]

37. Cowan, A.E.; Clark, S.J.; Gordon, J.L.; Bok, K.; Shen, A.K. Vaccine purchasing groups in the United States: An overview of their policies and practices. Vaccine 2016, 34, 5060-5065. [CrossRef]

38. Doucette, W.R. Influences on member commitment to group purchasing organizations. J. Bus. Res. 1997, 40, 183-189. [CrossRef]

39. Schotanus, F.; Telgen, J.; De Boer, L. Critical success factors for managing purchasing groups. J. Purch. Supply Manag. 2010, 16, 51-60. [CrossRef]

40. Vangen, S.; Huxham, C. Nurturing collaborative relationships: Building trust in interorganizational collaboration. J. Appl. Behav. Sci. 2003, 39, 5-31. [CrossRef]

41. Housley, C.E. Overcoming barriers to group purchasing. Hosp. Mater. Manag. 1982, 3, 73-86.

42. Johnson, P.F. The pattern of evolution in public sector purchasing consortia. Int. J. Logist. Res. Appl. 1999, 2, 57-73. [CrossRef]

43. Schneller, E.S. The Value of Group Purchasing -2009: Meeting the Needs for Strategic Savings; Health Care Sector Advances Inc.: Scottsdale, AZ, USA, 2009.

44. Cruijssen, F.; Cools, M.; Dullaert, W. Horizontal cooperation in logistics: Opportunities and impediments. Transp. Res. E Logist. 2007, 43, 129-142. [CrossRef]

45. Ireland, R.D.; Hitt, M.A.; Vaidyanath, D. Alliance management as a source of competitive advantage. J. Manag. 2002, 28, 413-446. [CrossRef]

46. Antosz, K.; Pacana, A. Comparative analysis of the implementation of the SMED method on selected production stands. Teh. Vjesn. 2018, 25, 276-282. 
47. Ates, M.A.; Van Raaij, E.M.; Wynstra, F. The impact of purchasing strategy-structure (mis) fit on purchasing cost and innovation performance. J. Purch. Supply Manag. 2018, 24, 68-82. [CrossRef]

48. Dana, M.J. Buyer groups as strategic commitments. Games Econ. Behav. 2012, 74, 470-485. [CrossRef]

49. Zhao, R.; Lan, Y. Asymmetric retailers with different moving sequences: Group buying vs. individual purchasing. Eur. J. Oper. Res. 2017, 261, 903-917.

50. Karjalainen, K. Estimating the cost effects of purchasing centralization-Empirical evidence from framework agreements in the public sector. J. Purch. Supply Manag. 2011, 17, 87-97. [CrossRef]

51. Hu, Q.; Schwarz, L.B.; Uhan, N.A. The impact of group purchasing organizations on healthcare-product supply chains. Manuf. Serv. Oper. Manag. 2012,14,7-23. [CrossRef]

52. Bals, L.; Laine, J.; Mugurusi, G. Evolving purchasing and supply organizations: A contingency model for structural alternatives. J. Purch. Supply Manag. 2018, 24, 41-58. [CrossRef]

53. Luzzini, D.; Longoni, A.; Moretto, A.; Caniato, F.; Brun, A. Organizing IT purchases: Evidence from a global study. J. Purch. Supply Manag. 2014, 20, 143-155. [CrossRef]

54. Zhanga, G.; Shangb, J.; Yildirim, P. Optimal pricing for group buying with network effects. Omega 2016, 63, 69-82. [CrossRef]

55. Schotanus, F. Cooperative purchasing within the United Nations. In Proceedings of the IPSERA Conference, Archamps, France, 20-23 March 2005; pp. 961-973.

56. Wooten, B. Cooperative purchasing in the 21st century. Inside Supply Manag. 2003, 14, 4-7.

57. Essig, M. Purchasing consortia as symbiotic relationships: Developing the concept of "consortium sourcing". Eur. J. Purch. Supply Manag. 2000, 6, 13-22. [CrossRef]

58. Laing, A.; Cotton, W.S. Inter-Organisational purchasing networks in the NHS. Eur. J. Purch. Supply Manag. 1997, 3, 83-91. [CrossRef]

59. Patterson, J.L.; Forker, L.B.; Hanna, J.B. Supply chain consortia:the rise of transcendental buyer-supplier relationships. Eur. J. Purch. Supply Manag. 1999, 5, 85-93. [CrossRef]

60. Ellram, L.M.; Carr, A.S. Strategic purchasing. A history and review of the literature. Int. J. Purch. Mater. Manag. 1994, 30, 2-8. [CrossRef]

61. Ellram, L.M. A managerial guideline for the development and implementation of purchasing partnerships. Int. J. Purch. Mater. Manag. 1991, 27, 2-8. [CrossRef]

62. Lambe, C.J.; Spekman, R.E.; Hunt, S.D. Alliance competence, resources, and alliance success: Conceptualization, measurement, andinitial test. J. Acad. Mark. Sci. 2002, 30, 141-158. [CrossRef]

63. Schotanus, F.; Telegen, J. Developing a typology of organisational forms of cooperative purchasing. J. Purch. Supply Manag. 2007, 13, 53-68. [CrossRef]

64. Safaei, A.S.; Heidarpoor, F.; Paydar, M.M. A novel mathematical model for group purchasing in health care. Oper. Res. Health Care 2017, 15, 82-90. [CrossRef]

65. Río, D.P.; Peñasco, C.; Mir-Artigues, P. An overview of drivers and barriers to concentrated solar power in the European Union. Renew. Sustain. Energy Rev. 2018, 81, 1019-1029.

66. Cagno, E.; Worrell, E.; Trianni, A.; Pugliese, G. A novel approach for barriers to industrial energy efficiency. Renew. Sustain. Energy Rev. 2013, 19, 290-308. [CrossRef]

67. Dahlqvist, A.; Soderholm, P. Industrial energy use, management practices and price signals: The case of swedish process industry. Int. J. Energy Econ. Policy 2019, 9, 30-45. [CrossRef]

68. Foggia, D.G.D. Effectiveness of energy efficiency certificates as drivers for industrial energy efficiency projects. Int. J. Energy Econ. Policy 2016, 6, 273-280.

69. Meijer, L.L.J.; Huijben, J.C.C.M.; Van Boxsteal, A.; Romme, A.G.L. Barriers and drivers for technology commercialization by SMEs in the Dutch sustainable energy sector. Renew. Sustain. Energy Rev. 2019, 112, 114-126. [CrossRef]

70. Foxon, T.J.; Gross, R.; Chase, A.; Howes, J.; Arnall, A.; Anderson, D. UK innovation systems for new and renewable energy technologies: Drivers, barriers and systems failures. Energy Policy 2005, 33, 2123-2137. [CrossRef]

71. Stoll, J.; Kopf, R.; Schneider, J.; Lanza, G. Criticality analysis of spare parts management: A multi-criteria classification regarding a cross-plant central warehouse strategy. Prod. Manag. 2015, 9, 225-235. [CrossRef]

72. Drezner, Z.; Scott, C.; Song, J. The central warehouse location problem revisited. IMA J. Manag. Math. 2003, 14, 321-336. [CrossRef] 
73. Aczel, A.D.; Sounderpandian, J. Complete Business Statistics, McGraw-Hill Primis, Boston, 2009. Complete Business Statistics, Boston; McGraw-Hill/Irwin: Boston, MA, USA, 2009.

74. Fahrmeir, L.; Kneib, T.; Lang, S.; Marx, B. Regression. Models, Methods and Applications; Springer: Berlin/ Heidelberg, Germany, 2013.

75. Lew, G. An Application of Statistical Methods in Financial Statements Auditing W: Quantitative Methods in Accounting and Finance, Red; Nowak, E., Motoryn, R., Eds.; Prace Naukowe UE we Wrocławiu nr 263: Wrocław, Poland, 2012; pp. 80-90.

76. Quayle, M. Purchasing in small firms. Eur. J. Purch. Supply Manag. 2002, 8, 151-159. [CrossRef]

77. Hu, Q.; Schwartz, L.B. Controversial role of GPOs in healthcare-product supply chains. Prod. Oper. Manag. Soc. 2011, 20, 1-15. [CrossRef]

78. Hendershott, T.; Jones, C.M.; Menkveld, A.J. Does algorithmic trading improve liquidity? J. Financ. $2011,66$. [CrossRef]

79. Schotanus, F.; Bakker, E.; Walker, H.; Essig, M. Development of purchasing groups during their life cycle: From infancy to maturity. Public Adm. Rev. 2011, 71, 265-275. [CrossRef]

80. Kurek, K.A.; Heijman, W.; Van Ophem, J.; Gędek, S.; Strojny, J. Geothermal spas as a local development factor, the case of Poland. Geothermics 2020, 85, 101777. [CrossRef]

81. Brodny, J.; Tutak, M. Analyzing similarities between the European Union countries in terms of the structure and volume of energy production from renewable energy sources. Energies 2020, 13, 913. [CrossRef]

82. Sarkar, M.; Sarkar, B. How does an industry reduce waste and consumed energy within a multi-stage smart sustainable biofuel production system? J. Clean. Prod. 2020, 262, 1-31. [CrossRef]

83. Zimon, G. An assessment of the strategy of working capital management in polish energy companies. Int. J. Energy Econ. Policy 2019, 9, 552-556. [CrossRef]

(C) 2020 by the authors. Licensee MDPI, Basel, Switzerland. This article is an open access article distributed under the terms and conditions of the Creative Commons Attribution (CC BY) license (http://creativecommons.org/licenses/by/4.0/). 